\title{
GOVERNMENT TO BAN ENERGY DRINK SALES TO CHILDREN IN ENGLAND
}

A ban on sales of energy drinks to children in England is to be introduced amid growing concern about the impact that the high-caffeine, high-sugar drinks are having on young people's health. A consultation on how to implement the proposed ban has been unveiled, with Downing Street indicating that the principal question to be determined is whether the purchasing restrictions will apply at the age of 16 or 18. A Downing Street source added that introducing a ban was all but certain, saying: 'It's a question not of whether we do it, but how.'

The principal justification for the ban is the high level of caffeine in the energy drinks which has been linked to health problems for children, including head and stomach aches, as well as hyperactivity and sleep problems. A $250 \mathrm{ml}$ can of Red Bull contains about $80 \mathrm{mg}$ of caffeine, roughly the same as a similarly sized cup of coffee, but three times the level of CocaCola. Monster Energy, which is often sold in larger cans of $500 \mathrm{ml}$, contains $160 \mathrm{mg}$ of caffeine. Energy drinks often also have higher levels of sugar than soft drinks. According to government figures, sugared energy drinks have $60 \%$ more calories and $65 \%$ more sugar than normal soft drinks and sugar is one of the largest causes of obesity.

\section{News briefs}

Kellogg's revamps its Coco Pops recipe The amount of sugar in Coco Pops breakfast cereal has been further reduced by $40 \%$. The revamped recipe, which also has $10 \%$ less salt, now has $17 \mathrm{~g}$ of sugar per $100 \mathrm{~g}$ rather than $30 \mathrm{~g}$. Levels were already cut by $14 \%$ this year. It puts the brand ahead of Government's goal of $20 \%$ less sugar in cereal and snacks by 2020 . Kellogg's said it took three-anda-half years to reformulate the recipe. Professor Graham MacGregor, chair of Action on Sugar, said: 'We hope Kellogg's will reformulate all of their cereals and set an example for all other food manufacturers. We need mandatory sugar-reduction targets with strict penalties for those who don't comply.

Poor mental health at work 'widespread' Poor mental health affects half of all employees, according to a survey of 44,000 people carried out by the mental health charity Mind. Only half of those who had experienced problems with stress, anxiety or low mood had talked to their employer about it. Fear, shame and job insecurity are some of the reasons people may choose to hide their worries. Mind says around 300,000 people lose their job each year due to a mental health problem. The charity - along with The Royal Foundation, Heads Together and 11 other organisations - has created an online resource for employers and employees with information, advice, resources and training that workplaces can use to improve wellbeing. The resource can be found here.

\section{NHS to be framehised around the globe}

It's been reported by the Daily Telegraph that the NHS is to be exported across the world as part of efforts to boost investment in Britain post-Brexit. Hospitals and health watchdogs are to be encouraged to set up franchises in dozens of countries, with profits ploughed into supporting the health service. Officials hope to turn the UK's national health service into a global brand, in the same way that the BBC gains significant income from its commercial BBC Worldwide arm.

\section{Onwards for Coca-Cola, downwards for dental health?}

Drinks giant Coca-Cola has agreed its biggest UK sponsorship deal by becoming Premier League football's seventh and final commercial partner. It will become the official soft drink partner of the league, joining other sponsors Barclays, Carling, Cadbury, Nike, Tag Heuer and EA Sports. The three-and-ahalf-year agreement starts in January 2019. The financial details have not been revealed. Coca-Cola also sponsors the football World Cup and the Olympic Games. The company, which employs 3,500 people in the UK, also owns Schweppes, Fanta, Sprite, and Oasis among others. 